\title{
Research and Development of STEAM (Science, Technology, Engineering, Animation, and Mathematics) the Problem-Based Learning for SMA XI Class Multimedia-Based
}

\author{
Sularso Budilaksono ${ }^{1}$, Lambas $^{2}$, Atep Kartiansyah ${ }^{3}$, Eko Hadi Prayitno ${ }^{4}$, Muhammad Anno \\ Suwarno $^{5}$ and Ahmad Rosadi ${ }^{6}$ \\ \{ sularso@upi-yai.ac.id ${ }^{1}$, lambas@kemdikbud.go.id ${ }^{2}$, kartiansyah.atep@gmail.com³, \\ eko_animated@yahoo.com ${ }^{4}$, suwarno@upi-yai.ac.id ${ }^{5}$, kangahmad@yahoo.com ${ }^{6}$ \} \\ Universitas Muhammadiyah Prof Dr Hamka, Indonesia ${ }^{123456}$
}

\begin{abstract}
Problem Based Learning (PBL) model is a way of learning where a problem as the starting point for learning. This study synthesizes and analyzes STEAM PBL in order to build the best model for students. The study developed a model by combining PBL with STEAM (Science, Technology, Engineering, and Mathematics Education). STEAM PBL has one of the elements is the animation process of the results of STEM learning. Many learning models in previous research only on Problem Based Learning, or only on STEM, but they are not a combination of PBL and STEAM. The study was conducted in three stages: introduction, development and implementation. STEAM development model in this study was developed by two approaches development unit STEAM learning PBL working with teachers who have run both the STEM learning embedded in a subject or across subjects. STEAM pilot study conducted PBL in some high schools were selected purposively and involves students and teachers. The test aims to implement the model STEAM PBL. Test results show that schools are not experiencing difficulties in implementing PBL STEAM coherently (preparation, process, products, publications, products, processes). STEAM implementation of PBL also rated very good support, develop and practice communication, collaboration, creativity and critical thinking of students. In response to indicators of Understanding between the components, Preparation, Process, Product, and Ecosystem STEAM PBL, and implementation and student responses are related to one another. Cross-tabulation tables show that the higher the score on a component the higher the score on other components, for example, the higher the score on Understanding the higher the score on Preparation.
\end{abstract}

Keywords: STEAM; Problem-Based Learning;

\section{Introduction}

The learning process is a process that contains a series of actions of teachers and students on the basis of reciprocity, which takes place in the educational situation in order to achieve certain goals. In the process of teaching and learning is going on two-way communication in studying a subject matter, was first taught by the teacher as an educator, while the second is a study conducted by the student or students. 
STEM is an acronym for science, technology, engineering, and mathematics. Said STEM launched by the National Science Foundation of the US in the 1990s as the theme of educational reform movements in the four areas of the discipline to grow the workforce STEM professions, as well as developing citizens literate STEM, as well as improving the global competitiveness of the US in the innovation of science and technology (Hanover Research, 2011). The reform movement STEM education is encouraged by reports of studies that show there is a shortage of candidates to fill jobs in areas of STEM, the level of literacy is significant in the community about issues related to STEM, as well as the position of the achievements of high school students as TIMSS and PISA (Roberts, 2012). Today the US commitment to the STEM education in the form of budget support from the government, the support of the expertise of many universities, and technical support from the industry, for the development and implementation of STEM education.

Today STEM Learning adopted by many countries as a blueprint for innovation in education, so that it appears as a global movement to bridge the gap between demand and availability of expertise needed for economic development in the 21 st century. Bureau of Labor Statistics in 2011 that outlines the scope of the global structure of the next decade STEM jobs will increase by $17 \%$, while the non-STEM jobs only increased by $10 \%$ (Kompas, July 12, 2015).

In the face of global competition, Indonesia also needs to prepare competent human resources in STEM disciplines in quality and sufficient quantity. As released in the newspaper Kompas (July 2015) Indonesia obstacle gap between demand and availability of resources. Referring to the Central Bureau of Statistics, 2010, Indonesian human resources still dominated power apes less skilled ( 88 million), and predicted 2020 will be a $50 \%$ shortage of labor to fill a vacancy in the structure of employment. However, the way to overcome this problem is not a simple matter, because no effort to develop basic skills, soft skills (collaboration, communication, creativity, problem-solving), and the values of the prerequisites to enter the profession of STEM at the level of primary and secondary education, it is difficult to expect a generation young motivated and ready to pursue STEM fields.

Learning experiences in science-based STEM learning can be expected as well as developing an understanding of learners to the content of science, innovation and the ability to problem-solving, soft skills (such as communication, teamwork, leadership). The impact of further study of science-based STEM is increasing the interest and motivation of students to pursue studies and careers in the field of science and technology professions, as required state today and in the future.

\section{Relevance Research}

Problem Based Learning is often referred to as PBL is one of the student-centered manners exposes learners to the various problems faced in life. PBL learning is a way of presenting the material subject to the problem as a starting point for discussion analyzed and synthesized in an attempt to find solutions or answers by students. Thus, PBL is a method of learning that focuses on tracking the root of the problem and solve the problem (Liu et al., 2012).

Learning STEM-based learning requires a shift in the method of assessment, assessment of the conventional focus on testing with a test toward authentic assessment based on performance evaluation. Performance assessment using the rubric of a well-designed to be a 
teacher, friend, and learners themselves to the performance of students during the learning activities and products of collaborative work to uncover the accessibility standards of learning (Kelley and Knowles, 2016).

Some previous research is relevant:

a. Jeong, Sophia Kim, Hyoungbum with the title "The effect of a climate change monitoring program on students' knowledge and perceptions of STEAM education in Korea"[1]. Overall, high school students must acquire the knowledge content STEAM for monitoring the GCC. More positive perception of science, technology, engineering, arts, and mathematics appear in STEAM.

An increase in students' perceptions of their own STEAM trend seems to be the result of additional projects. Profit for female students is significant. Further research is needed to confirm these findings on a larger scale. Also, future studies can randomly place students in conditions, while it may face serious practical challenges, will give a generalization of experimental results are greater.

b. Nam Ju Kim and Brian R. Belland and Andrew E. Walker entitled "Effectiveness of Computer-Based Scaffolding in the Context of Problem-Based Learning for Stem Education: Bayesian Meta-analysis" [2] Bayesian simulation study, the effect size estimate accurate than six moderators (a total of 24 subcategories) associated with the characteristics of the scaffold and context-based computers use scaffolding. BMA results show that computer-based scaffolding significantly affect $(g=0.385)$ results in cognitive problem-based learning in STEM education.

In addition, in accordance with the characteristics and context of the use of scaffolding, scaffold-based computer effects vary with the range of small to moderate. Results BMA contribute to improved understanding of the effects of scaffold-based computer in problem-based learning.

c. Min Liu, entitled "Examining How Middle School Science Teachers Implement multimedia-enriched Problem-based Learning Environment"[3]. The study identified four factors that affect the motivation of teachers in adopting and using the PBL program at neighborhood schools. Practical implementation of the teacher is documented in detail. Given the findings of this study, we realized that to understand and evaluate the effectiveness of PBL-based technology is a task that is more challenging and nuanced than simply comparing the results of the study based on the presence or absence of PBLbased technology.

d. Todd R Kelley and J. Geoff Knowles with the title "A conceptual framework for integrated STEM education"[4]. STEM education literature recently gave reason to teach STEM concepts in the context of the most often delivered in the project, problems, and design-based approach. This can prove helpful if integrated STEM educators learn the "language STEM" and STEM practices described above.

e. Suri Hapiziah, Simon Suhery, Jejem Mujamil S with the title "Development of Material Chemistry Matter Reaction Rate-Based Stem Problem-Based Learning Class Xi SMA Negeri 1 Indralaya North"[5]. Results study class test 0.76 (very effective), while the regular classroom 0.60 (effective).

Based on N-Gain results show that students learn to use teaching materials based on STEM Problem-Based Learning is better than the results of students who do not use the material-based STEM Problem-Based Learning. The above-stated material reaction-based STEM Problem-Based Learning valid, practical and effective. Advice for researchers and students to teachers to use teaching materials based on STEM Problem-Based Learning in the learning process. 
f. Ratna Farwati, Anna Permanasari, Harry said, Simon Suhery with the title "Integration Problem Based Learning in STEM Education Oriented Actualization Environmental Literacy and Creativity"[6]. learning or skills that can be supplied to the students. Curriculum and teaching materials on the subjects of Environmental Chemistry, for example, can accommodate the development of the literacy environment and creativity of students. Environmental Chemistry examines the solution of environmental problems from various perspectives in science.

Thus, Environmental Chemistry is organized with proper multidisciplinary approach as a combination of science, technology, engineering, and mathematics (STEM). Raise environmental issues is appropriate to approach problem-based learning (PBL). Integration of PBL in STEM is possible to actualize the literacy environment and the creativity of the students.

g. Ani Ismayani with the title "Corporate Governance Stem Project-Based Learning on Mathematical Creativity School Students" [7]

\section{Methodology}

This research method using Research and Development (Dick and Carey, 1998). There are three stages: introduction, development, and implementation. Preliminary phases: (1) Identify the instructional objectives (Assess Needs to Identify Instructional Goals). (2) Conduct Instructional Analysis (Conducting Instructional Analysis). (3) Production of earlystage, (4) Formulate goal performance (Write Performance Objectives), (5) Development Test Reference Standard (Developing Assessment Instruments). (6) Development of strategy Teaching (Develop Instructional Strategy), (7) the development of Choosing Teaching (Develop and Select Instructional Materials), (8) Designing and Implementing Formative Evaluation (Design and Conduct Formative Evaluation and Instruction), (9) Revision Learning (Instructional Revisions). (10) Designing and Implementing Summative Evaluation (Design and Conduct summative evaluation) of Dick and Carey, selected with consideration of the suitability of the material developed.

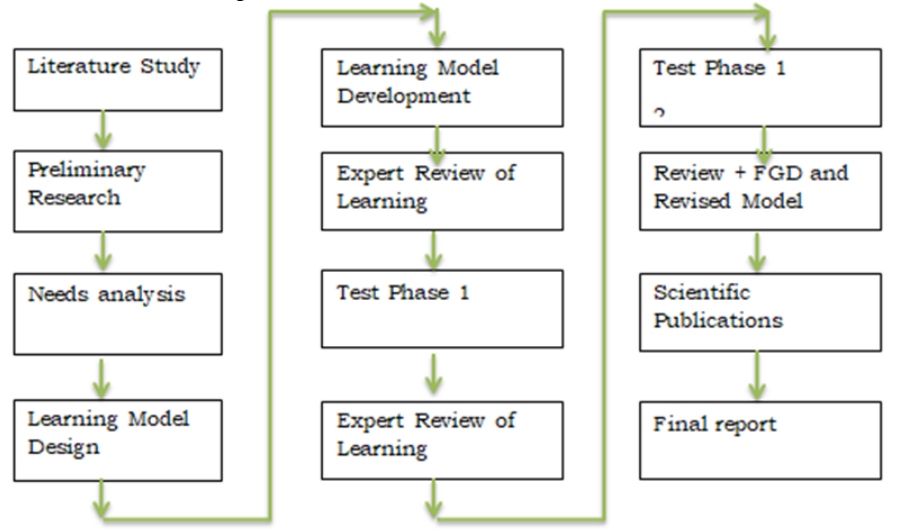

Fig 1. Research Framework 


\section{Result and Discussion}

This study developed a model combining Problem-Based Learning with STEAM (Science, Technology, Engineering, and Mathematics Education) so that there is an element of animation in STEM. Learning model in previous research only on alloy Problem-Based Learning and STEM course or alloys Project-Based Learning and STEM. Learning model that can be developed to implement the 5 pillars of education are: Learning to believe, learning to know, learning to do, learning to live together, learning to be, so it can strengthen character education both personal character and performance. The model is expected to improve the quality of education with the implementation approach scientific, learning 21st century include $4 \mathrm{C}$ is Collaboration, Critical Thinking, Communicative and Creative and fulfilling learning HOTS (High Order Thinking System), and the International Valuation Standards including assessment authentic, and KI and KD. In this research model applied to subjects that involve multiple disciplines in high school class XI, in contrast to previous research only on one subject only.

STEAM development model in this study was developed by the two approaches development unit STEAM learning PBL working with teachers who have run both the STEM learning embedded in a subject or integrated across subjects. Then the development of multimedia learning STEAM PBL working with students of Art University District with the aim of learning that has been developed can be made visualizing and can easily be disseminated to the wider community. Results of STEAM PBL embedded to 1 subjects has resulted in: (1) Unit of STEAM PBL were pinned on subjects Physics under the title "The Fluid Static form of prototype submarine", (2) Unit of STEAM PBL embedded in science subjects biologists with the title "Big Sweet Ranginang, Healthy Menu Food Specialties, carefree Heart Glad", (3) Unit of STEAM PBL embedded in Mathematics with the title "learning Matrix in Making Ice Candle traditional", (4) Unit of STEAM PBL pinned on subjects Informatics titled "Making Creative Products Augmented Reality (EXPERT)", (5) Unit PBL learning STEAM pinned on subjects Social Entrepreneurship with the title "Urban Farming as a solution to labor".

Developing STEAM PBL embedded to cross subjects has resulted in: (1) Cross Subjects Biology, Chemistry, Economics and Construction Topics Making egg incubator, Cross Subjects Biology, Physics, Physics, and Mathematics Topic Making a hinge joint, (2) Cross Subject Chemistry, Physics, and Biology topic Creation Tool Makers Heat BBM Save Energy, (3) Traffic subjects Chemistry, Physics, Mathematics, Arts and crafts Topics Making a Rocket Launcher Simple, (4) Traffic subjects Chemistry, Physics, Mathematics, Engineering and Technology, Basic Electronics and instrument Making Animation Topics Fire Detection [8]. Results of development by a team of authors consisting of researchers and teachers are validated by SEAMEO Qitep in Science and P4TKIPA and published in book form as shown in the following figure.

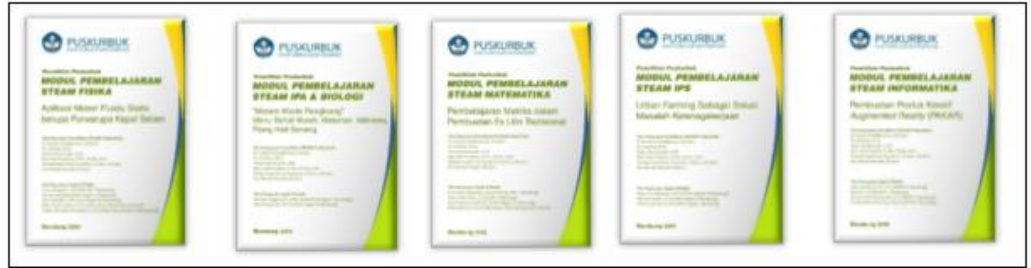

Fig 2. Learning Modules of STEAM PBL Embedded on a Subject 


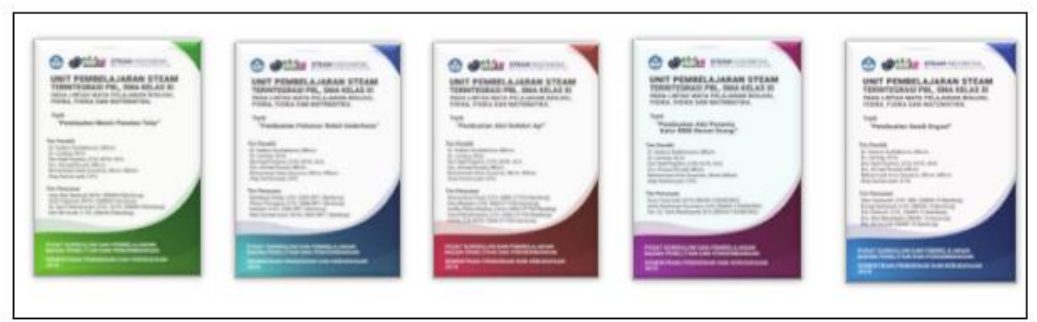

Fig 3. Learning Modules of STEAM PBL Integrated Across Subjects

Development of multimedia learning STEAM PBL done to facilitate the understanding and dissemination of information about the unit STEAM learning PBL to teachers, students, and the wider community. Development is done with regard to the legal aspects of the design and make their own multimedia components and aspects of interactivity that users can use it easily. Zoom can be seen briefly in the image below.

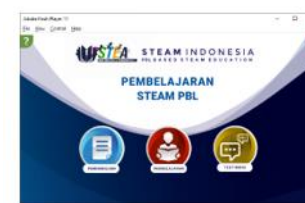

(a)

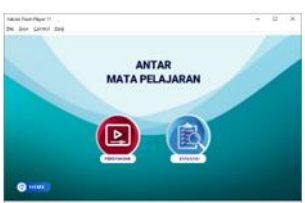

(c)

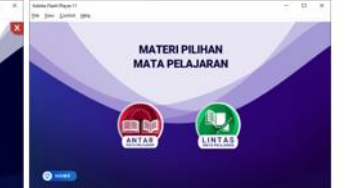

(b)

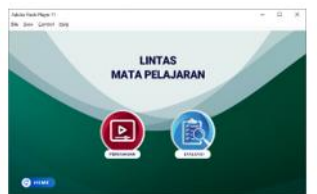

(d)

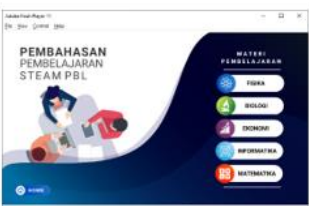

(e)

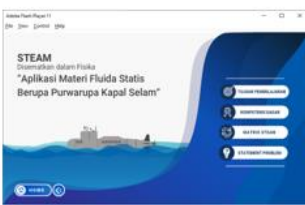

(g)

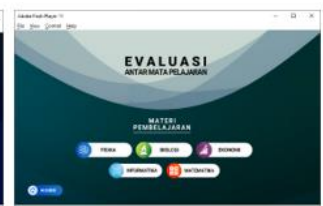

(f)

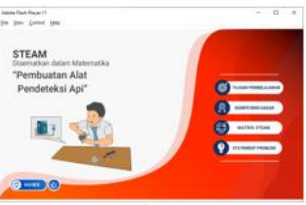

(h)

Fig 4. Feature of Multimedia Applications STEAM PBL

Respondents in this study are the teachers and students who live test STEAM PBL learning so they can tell the understanding of learning through a questionnaire that has been prepared. STEAM learning PBL cross subjects, there are 172 respondents, respondent's teacher is 45 and the number of respondents is 125 students and people who do not fill out the category is 2 . Profile of respondents-based group that teachers and students are as follows:

Table 1. Profile of respondents of STEAM-PBL

\begin{tabular}{|c|c|c|c|c|c|}
\hline \multicolumn{2}{|c|}{ Status dan category } & Frequency & Percent & $\begin{array}{c}\text { Valid } \\
\text { Percent }\end{array}$ & $\begin{array}{c}\text { Cumulative } \\
\text { Percent }\end{array}$ \\
\hline \multirow{3}{*}{ Valid } & Guru & 45 & 25.6 & 26.5 & 26.5 \\
\cline { 2 - 6 } & Siswa & 125 & 72.7 & 73.5 & 100.0 \\
\cline { 2 - 6 } & Total & 170 & 98.8 & 100.0 & \\
\hline Missing & System & 2 & 1.2 & & \\
\hline \multicolumn{2}{|c|}{ Total } & 172 & 100.0 & & \\
\hline
\end{tabular}

These research trials are applied to a sample of schools located in Bandung and Jakarta. The test is done to measure the understanding, preparation, process, product, and 
implementation of ecosystem model STEAM PBL previously developed. The measurement results can be seen in the following description.

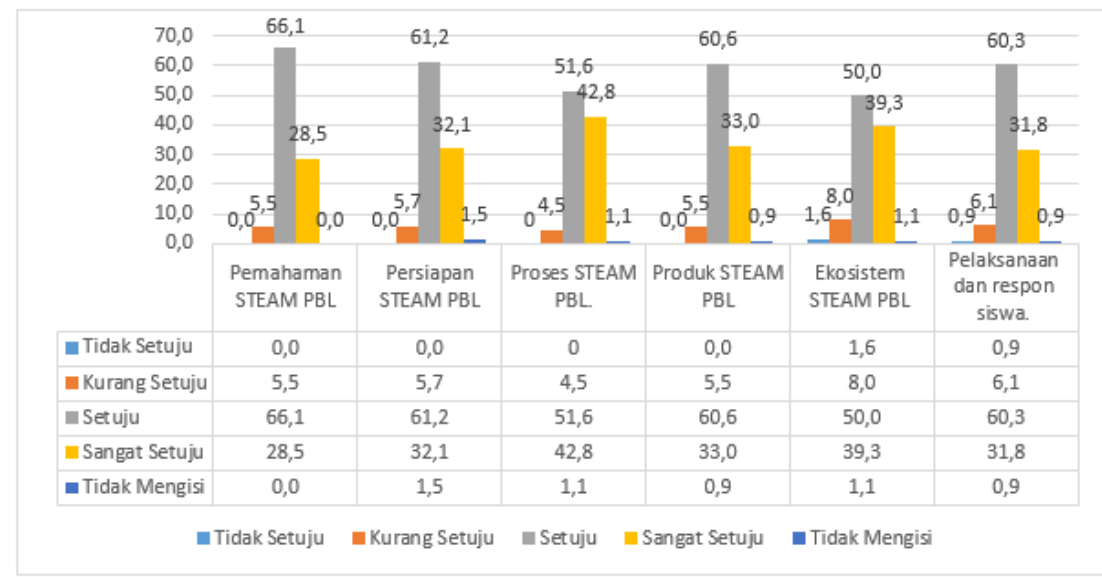

Fig 5. Response to STEAM PBL Embedded to a Particular Subject

Respondents' answers to a questionnaire indicator such understanding, Preparation, Process, Product, and Ecosystem STEAM PBL, and implementation can be analyzed. Analytical results are that respondents are interconnected with one another. Cross-tabulation tables show that the higher the score component of the higher than it will affect the score of the other components. The respondents, for example, the higher the score on Understanding the higher the score on Preparation.

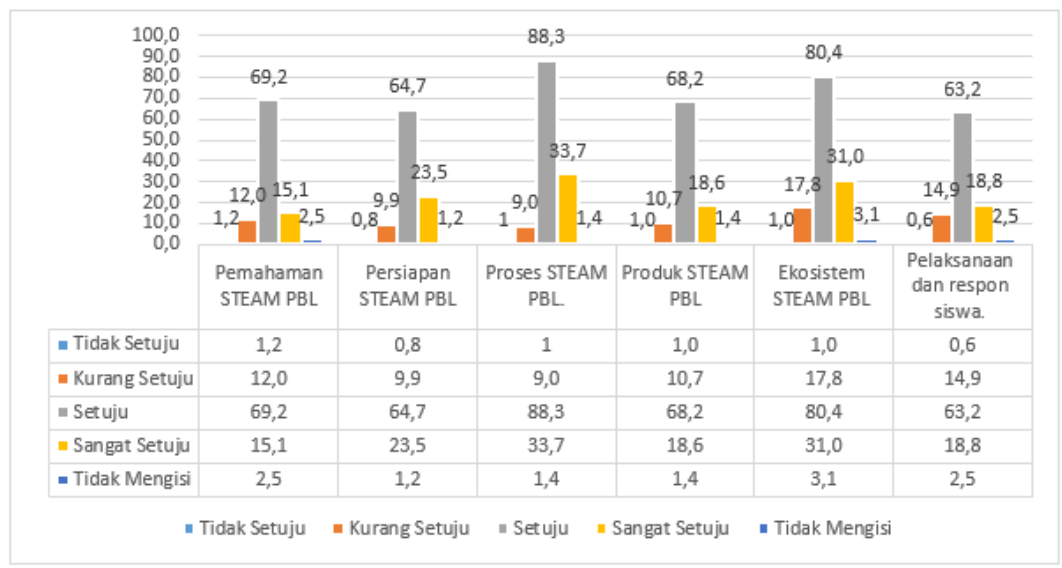

Fig 6. Response to STEAM PBL Integrated across Subjects

Respondents to the questionnaire as an indicator of Understanding, Preparation, Process, Product, and Ecosystem STEAM PBL, PBL and implementation can be analyzed. The results of respondent's students is that the answers are related to one another. Cross-tabulation tables show that cross the higher score on a component the higher the score on other components, for example, the higher the score on Understanding the higher the score on Preparation.

This study also found that the application of PBL STEAM can be run sequentially starting from the preparation, process, products, publications and learning. Test learning 
STEAM PBL can be implemented well by the schools to study these samples SMAN 8 Bandung, SMA BPI Bandung, SMAN 10 and SMAN 1 Bandung and Jakarta, and high school. The ability of teachers to prepare materials and materials for the learning process is necessary for the successful implementation of this STEAM PBL. Students are more motivated in learning, very fun, and students actively and creatively in solving a given problem. STEAM implementation of PBL also very supportive, develop and practice communication, collaboration, creativity and critical thinking. Many students and the group can trigger creative ideas that are useful for school.

\section{Conclusion}

Based on the above discussion, the following points are concluded:

a. Development of learning STEAM PBL modules by involving teachers and students have produced modules that are very good. This shows that the teachers in the sampled schools in the study developed a module STEAM PBL are quite good.

b. Teachers and students can implement modules STEAM PBL systematically.

c. Student's response to the indicators is interconnected. Cross-tabulation tables show that higher the score on one component higher the score on other components, for example, higher the score on Understanding higher the score on Preparation. Animation and multimedia support learning process creatively as well the documentation so it can be used to learn more creatively.

d. The whole process of learning STEAM PBL can be implemented in schools if the facilities and materials are available and teachers' understanding of the learning modules are sufficient.

\section{References}

[1] Jeong, Sophia, and Hyoungbum Kim. 2015. "The Effect of a Climate Change Monitoring Program on Students' Knowledge and Perceptions of STEAM Education in Korea." Eurasia Journal of Mathematics, Science and Technology Education 11(6): 1321-38.

[2] Kim, Nam Ju, Brian R. Belland, and Andrew E. Walker. 2018. "Effectiveness of Computer-Based Scaffolding in the Context of Problem-Based Learning for Stem Education: Bayesian MetaAnalysis.” Educational Psychology Review 30(2): 397-429.

[3] Liu, Min, et al. 2012. "Examining How Middle School Science Teachers Implement a MultimediaEnriched Problem-Based Learning Environment." Interdisciplinary Journal of Problem-Based Learning 6(2).

[4] Kelley, Todd R., and J. Geoff Knowles. 2016. "A Conceptual Framework for Integrated STEM Education.” International Journal of STEM Education 3(1). http://dx.doi.org/10.1186/s40594-0160046-z.

[5] Hapiziah, Suri, Tatan g Suhery, and Jejem Mujamil S. 2015. "Pengembangan Bahan Ajar Kimia Materi Laju Rekasi Berbasi STEM Problem-Based Learning Kelas XI SMA Negeri 1 Indralaya Utara.” Jurnal Penelitian Pendidikan Kimia: Kajian Hasil Peneltiian Pendidikan Kimia 2(2): 20619.

[6] Farwati, Ratna, Anna Permanasari, Harry Firman, and Tatang Suhery. 2015. "Integrasi Problem Based Learning Dalam STEM Education Berorientasi Pada Aktualisasi Literasi Lingkungan Dan Kreativitas." : 198-206.

[7] Ismayani, Ani. 2016. "Pengaruh Penerapan STEM Project-Based Learning Terhadap Kreativitas Matematis Siswa SMK.” Indonesian Digital Journal of Mathematics and Education 3: 264-72. 
[8] Berti Yolida, Ranthy Ajeng Damarwulan, Darlen Sikumbang. 2020. "Hubungan Pelaksanaan Praktikum dan Keterampilan Generik Sains terhadap Hasil Belajar Peserta Didik". Bioeduscience. 4(1): $56-65$ 